\title{
ЭКСПОЗИЦИОННАЯ ДЕЯТЕЛЬНОСТЬ НА ТЕРРИТОРИИ КАВКАЗСКОГО КРАЯ В СОСТАВЕ РОССИЙСКОЙ ИМПЕРИИ КАК ВОЗМОЖНОСТИ ПРОЯВИТЬ СВОЙ ПОТЕНЦИАЛ ДЛЯ КАРССКОЙ ОБЛАСТИ. ЗНАЧЕНИЕ И ПЕРСПЕКТИВЫ (1850 - 1912 ГГ.)
}

\section{EXHIBITION ACTIVITIES ON THE TERRITORY OF THE CAUCASUS REGION WITHIN THE RUSSIAN EMPIRE AS \\ AN OPPORTUNITY TO SHOW THEIR POTENTIAL FOR THE KARS REGION. SIGNIFICANCE AND PROSPECTS (1850-1912)}

\section{Pestovskaia}

Summary: The article is dedicated to the development of exhibition activities in the territory of the Caucasus district and the Kars region, which is part of it. Over a long period of time from 1850 to 1912, numerous attempts were made to interest the local population and convince them of the need and importance of holding such cultural and educational events that contribute to improve relations between the peoples inhabiting the region, creating favorable socio-economic conditions that affect the development and improvement of methods of conducting crafts in the region and the exchange of valuable and rich experience in the field of agriculture, industry and various types of crafts.

Keywords: the Caucasian district, the Kars region, the Russian Empire, exhibition, exhibition activities, agriculture, farming, gardening.
B состав Кавказского округа входили 7 губерний: Ставропольская, Тифлисская, Кутаисская, Елизаветпольская, Бакинская, Эриванская и Черноморская; и 5 областей: Кубанская, Терская, Дагестанская и недавно вошедшие Батумская и Карсская'.

Каждый регион Кавказского округа имел свои отличительные особенности в сфере культуры, образования, хозяйства и т. д. Карсская область не была исключением: несмотря на сложное политическое и экономическое положение, Карсский регион обладал потенциалом и уже развитыми на тот момент видами сельскохозяйственной деятельности и промыслов, которые требовали своего усовершенствования. Для Карсской области
Пестовская Дарья Александровна

Аспирант, ФГБОУ ВО Санкт-Петербургский государственный университет (2. Санкт-Петербург) daryagreen@yandex.ru

Аннотация: Статья посвящена развитию выставочной деятельности на территории Кавказского округа и Карсской области, входящей в его состав. На протяжении долгого периода времени с 1850 по 1912 годы были предприняты многочисленные попытки заинтересовать местное население и убедить его в необходимости и важности проведения такого рода культурно-просветительских мероприятий, способствующих улучшению отношений между народами, населяющими регион, созданию благоприятных социально-экономических условий, влияющих на развитие усовершенствование методов ведения промыслов в регионе и обмену ценным и богатым опытом в сфере сельского хозяйства, промышленности и разного вида ремесел.

Ключевые слова: Кавказский округ, Карсская область, Российская Империя, выставка, экспозиционная деятельность, сельское хозяйство, земледелие, огородничество, садоводство. потенциальное участие в выставке предоставляло для нее возможность продемонстрировать свои возможности и ценный потенциал в огородничестве, садоводстве, скотоводстве, хлебопашестве, ковроткачестве, сыроварении и изготовлении иных молочных продуктов, добыче полезных ископаемых и т.д.

Хотя на протяжении всего периода пребывания Карсской области в составе Российской Империи постоянно присутствовали трудности политического, социальноэкономического и культурного характера, Правительство предпринимало всевозможные усилия для улучшения ситуации в регионе и вкладывало как можно больше средств на его развитие (установление порядка, распре-

1 Кавказский Календарь на 1890 год, Оглавление. 
деление земель, урегулирование религиозного вопроса, создание учебных заведений и т.д.) $)^{2}$.

Еще в 1850 году Светлейший Князь Михаил Николаевич Воронцов утвердил создание Кавказское Общество Сельского Хозяйства, которое, в свою очередь, организовало в том же году экспозицию по проекту барона Мейендорфа «Выставка естественных и мануфактурных произведений Кавказского и Закавказского края», длившуюся с 6 по 31 марта 1850 года и основными целями которой являлись знакомство населения региона с промыслами и продуктами, а также всем тем, чем был богат Кавказский и Закавказский край; способность проанализировать и дать возможность Правительству региона оценить качество продуктов, изготовляемых в местностях; выявление усовершенствованных способов и методов изготовления продукции; отправление лучшую продукцию на выставки в Санкт-Петербург и Москву для того привлечения русских купцов в качестве потенциальных покупателей сельскохозяйственной продукции Кавказского и Закавказского края. Выставка прошла успешно: 39 экспонентов представили посетителям около двух тысяч образцов своей продукции ${ }^{3}$.

В свою очередь в октябре 1852 года в городе Тифлис была проведена выставка огородных произведений, в которой приняло участие 9 экспонентов с 288-ю образцами своей продукции. В конце выставки участники были награждены ценными призами.

В дальнейшем после Князя Воронцова Князь Баратинский выступил ответственным лицом за реализацию выставочной деятельности, а именно создал в 1857 года при Кавказском Обществе Сельского Хозяйства ежегодные выставки Кавказских сельскохозяйственных и промышленных произведений. Победителей данных выставок выбирал лично Наместник, которые награждались щедрыми призами и подарками (к примеру, вручались золотые медали на аннинской ленте). Однако, следует отметить, что участники не проявляли столь большого желания в участии в выставках по следующим возможным причинам: с одной стороны это дискомфорт и некомфортные условия для производящих продукцию местных жителей, а именно потенциальных экспонентов, которых приглашают участвовать из года в год в мероприятиях; с другой стороны, это неполная осознанность важности и значимости выставок для населения региона. Так, князь Баратинских принял решение об утверждении одной постоянной выставки, вместо ежегодных, вследствие невозможности достижения больших результатов в промышленности и сельском хозяйстве, отсутствия постоянного интереса и мотивации в участии на выставках. Единая выставка же могла способствовать взаимной помощи конкурсантов на выставке друг друга, изучая опыт и учась друг у друга на ошибках; кроме того, Правительству и Кавказскому Обществу Сельского Хозяйства открывалась возможность наблюдения за развитием или угасанием темпов различных видов промыслов на территории всего региона4. Таким образом, постоянная выставка представляла собой «<...>учрежденіе, въ которое каждый производитель или экспонентъ имълъ бы право и возможность во всякое время представлять свои произведенія. Присылаемые образцы произведеній должны оставаться на виду не менъе 6-ти мъсяцевъ. По истеченіи этого времени, каждый образецъ, если онъ не будетъ проданъ, возвращается производителю, которому, смотря по присужденію особаго комитета, подъ руководствомъ Совъта Общества, можетъ быть присуждена одна изъ наградъ, предоставленныхъ праву его; образцы-же естественныхъ произведеній различныхъ частей края и сырыхъ продуктовъ остаются невозвращенными, составляя такимъ образомъ постоянный музей всъхъ разнородныхъ богатствъ, который будетъ постепенно пополняться и возобновляться. Черезъ каждые два года въ извъстное, однажды навсегда опръделенное, время года, должна быть учреждена генеральная выставка, при обсужденіи которой экспонентамъ присуждаются высшія награды» ${ }^{5}$ Но, к сожалению, подающий большие надежды проект постоянной выставки князя Баратинского, не осуществились. Со временем среди населения угасал интерес и к временным выставкам. Запланированная на 1863 год выставка была перенесена на 1869 год, на которой были представлены домашние животные и скотоводческая продукция. В ней приняли участие 280 экпонентов, некоторым из которых были вручены 29 медалей (7 золотых и 3 серебряных).

К 1888 году в Кавказском Обществе Сельского Хозяйства во главе с Князем Главноначальствующим гражданской частью на Кавказе А.М. Дондуковым-Корсаковым вновь стал активно обсуждаться вопрос о возможном проведении выставки, на что было дано согласие и одобрение Министра государственных имуществ, который выделил 10000 рублей на проведение данного мероприятия ${ }^{6}$. Так, совместными усилиями Правительство, Кавказское Общество Сельского Хозяйства и Тифлисское городское управление приступили к организации выставки, предварительно составив программу мероприятия 7 .

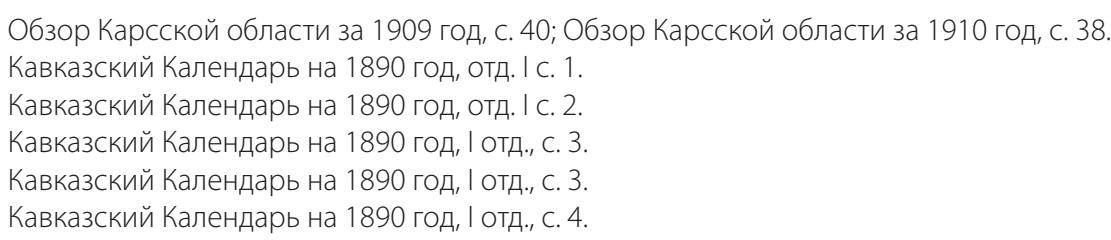


Так, совместными усилиями был разработан план по проведению и реализации масштабного мероприятия. Именно на плечи Распорядительного Комитета пала главная трудность - суметь уговорить и убедить местное население, чтобы те заинтересовались и проявили интерес по отношению к выставке, а также позволили представить там свою продукцию. Кроме того, организаторы выставки были вынуждены взять на себя материальную часть вопроса, а именно оплату доставки продукции на выставку ${ }^{8}$.

Русским и иностранным компаниям были разосланы приглашения на выставку․․ В момент прибытия участников и гостей выставки, экспозиция была украшена цветочными композициями; в большом деревянном здании, украшенном флагами, располагался основной корпус. Для экспозиции было выделено 50 дополнительных павильонов. Вся выставка была разделена на 9 секций ${ }^{10}$. На экспозиции были представлены, главным образом промышленные промыслы и ремесла, Тифлисская школа садоводства, педагогически-профессиональный отдел Кавказского учебного округа. Следовательно, данная выставка, благодаря своему внешнему виду и содержательной части, способствовала осознанию среди местного населения, какими богатствами в действительности обладает описываемый регион. К тому же и власти могли проанализировать и рассмотреть всевозможные проекты по дальнейшему благоустройству и процветанию Кавказского и Закавказского края ${ }^{11}$.

Карсская область представила гостям 8 пудов $\left(131,045\right.$ кг $\left.^{12}\right)$ пшеницы, 8,4 пудов ячменя $\left(137,598\right.$ кг $\left.^{13}\right)$ и 16,5 пудов хлеба $\left(270,2813\right.$ кг $\left.^{14}\right)$, приняв участие в секции хлебопашества ${ }^{15}$. Кроме того, 8 представителей из Карсской области, занимавшиеся огородничеством и садоводством, приехали на выставку и представили свою продукцию ${ }^{16}$. Кроме того, Карсская область приняла участие и в других секциях, как, например, скотоводство, фабрично-заводская деятельность, кустарные промыслы и педагогический отдел, завоевав всего 2 малых серебряных и 5 бронзовых медалей, а также 20 похвальных листов ${ }^{17}$.
В целом, в данной выставке приняло участие 4000 экспонентов: было выдано всего 1009 наград ${ }^{18}$.

Со временем в Обзоре Карсской области на 1909 год впервые было предложено провести самостоятельную выставку промышленности и сельского хозяйства в Карсской области в самое ближайшее время, для того чтобы показать не только Правительству, но и самому населению в целом, чему научились и чего достигли местные жители и переселенцы за период этот период времени, начиная с 1878 года. В документе отмечалось, что со времени присоединения региона к Российской Империи были развиты такие промыслы, как огородничество, садоводство, скотоводство, было поднято на более хороший уровень земледелие и хлебопашество; были такие кустарные промыслы, как ковроткачество и пошив тканей; существовал ряд каменоломен и залежей полезных ископаемых и минеральных богатств. Не только русские переселенцы, но и в дальнейшем местные жители старались улучшить свои земледельческие хозяйства и усовершенствовать свои навыки ${ }^{19}$.

В Обзоре отмечалось, что необходимо было бы создать отдельную секцию для тех фирм, которые вели сотрудничество с Турцией и Персией (Ираном), чтобы в дальнейшем на экспозиции местное население познакомилось с продукцией внутреннего и внешнего рынков. В то время Турция и Персия (Иран) играли важную роль в экономике государства, поэтому было очень важно акцентировать внимание на экономических и социокультурных отношениях между Карсской областью, вошедшей в состав Российской Империи и Персией и Турцией ${ }^{20}$

Однако в связи с холерой, бушевавшей на протяжении 1910 года, проведение запланированной первой сельскохозяйственной и промышленной выставки в Карсской области перенесли на 1912 год. В Обзорах Карсской области за 1909 и 1910 годы неоднократно подчеркивалось значение проведения выставки и ее положительные последствия, а именно: освещение всех основных промыслов Карсской области, знакомство местных жителей с продукцией друг друга и обмен на-

8 Кавказский Календарь на 1890 год, І отд., с. 4-5.

9 Кавказский Календарь на 1890 год, I отд., с. 10.

10 Кавказский Календарь на 1890 год, І отд., с. 15.

11 Кавказский Календарь на 1890 год, І отд., с. 10-12.

12 Примечание автора статьи Пестовской Д.А.

13 Примечание автора статьи Пестовской Д.А.

14 Примечание автора статьи Пестовской Д.А.

15 Кавказский Календарь на 1890 год, І отд., с. 21.

16 Кавказский Календарь на 1890 год, І отд., с. 37.

17 Кавказский Календарь на 1890 год, І отд., с. 73-74.

18 Кавказский Календарь на 1890 год, І отд., с. 75.

19 Обзор Карсской области за 1909 год, с. 40-41; Обзор Карсской области за 1910 год, с. 41.

20 Обзор Карсской области за 1909 год, с. 41-42; Обзор Карсской области за 1910 год, с. 41-42. 
копленным за многие годы опытом²1.

В июне 1912 года в городе Карс была открыта первая выставка животноводства и животноводческой продукции Карсской области ${ }^{22}$. После того, как Военный губернатор Карсской области Генерал Петр Федорович фон Паркау и главный священник Комар произнесли свои вступительные речи и молитвы, торжественно открылась выставка, организованная в честь 35-летия вхождения в состав Российской Империи. После произнесенных православным священником молитв, молокане, в свою очередь, также помолились, согласно своим религиозным верованиям и обычаям. В выставке, главным образом, приняли участие молокане, приехавшие из таких деревень и селений, как Ново-Александровка, Хаджи Халиль, Владикарс, Ново-Селим, Благодарное, Родионовка, Ново-Воронцовка, Харам Вартан, Бендеван, Джелаус и др. После того, как прозвучали приветственные речи, молокане пригласили всех гостей выставки на чаепитие. Посетителям были предложены в качестве угощения к чаю масло, сыр, сливки и другие продукты, приготовленные самими молоканами. Во время чаепития подполковник Семен Спиридонович Эсадзе также произнес речь.

Те жители, кто занимался вскармливанием животных и скота, приняли участие в соревновании со 165-ю животными. По итогам жюри, обладателями больших серебряных медалей стали Федор Малофеев из деревни Ново-Воронцовка, двухгодовалый бык по кличке Юнга и шестилетняя корова Машка из деревни Владикарс. Кроме того, малые серебряные и бронзовые медали и похвальные листы были вручены хозяевам животных. Вдобавок ко всему вышесказанному, всем участникам было вручено по 5 рублей. Во время проведения выставки были устроены различные симпозиумы и семинары, представлены различные доклады научной направленности ${ }^{23}$.

Отсутствие должного уровня образования и пред- ставления о ведении сельского хозяйства среди местного населения, их нежелание и неумение пользоваться усовершенствованными техническими приспособлениями в хозяйстве; недостаточное количество специальных ремесленных школ и образовательных учреждений - все это негативно влияло на развитие существующих и потенциальных промыслов на территории описываемого региона ${ }^{24}$.

\section{Зак^ючение}

В течение 1850-1912 гг. была проведены поэтапные подготовительные работы с результатами в качестве выставок 1889 и 1912 годов на территории Кавказского округа и отдельно в Карсской области. Это говорит о том, что не только Правительство, но и со временем само население региона предпринимало всевозможные попытки для улучшения жизни в разных сферах деятельности. Так, в экономическом, политическом и культурнопросветительском отношении выставки, открытые при Кавказском Обществе Сельского Хозяйства, стали очень важной частью развития всего Кавказского региона. Так, первая постоянная выставка 1889 года показала основной потенциал губерний и областей Кавказского округа, в которой приняла участие также и Карсская область, в которой уже на тот момент времени удалось завоевать призовые места в сфере огородничества, садоводства и скотоводства и признание властей и местных жителей. В свою очередь, в самой Карсской области, обладавшей всем возможным потенциалом к своему развитию после нескольких попыток организации там первой областной выставки, лишь в июне 1912 года в Карсе была организована и успешно проведена выставка по животноводству и животноводческим продуктам, что привело к еще большему развитию продукции и ведению самого сельского хозяйства, знакомству населения с навыками производителей региона, обменом опыта между жителями Кавказского региона и расширению экономических и культурных связей.

\section{ЛИТЕРАТУРА}

1. Кавказский Календарь за 1877 год: 32-й год. - 1876. - Тифлис: Гл. упр. Кавказ. наместника, 1845-1916. - 632 с.

2. Кавказский Календарь за 1878 год: 33-й год. - 1877. - Тифлис: Гл. упр. Кавказ. наместника, 1845-1916. - 603 с.

3. К Кавказский Календарь за 1879 год: 34-й год. - 1878. - Тифлис: Гл. упр. Кавказ. наместника, 1845-1916. - 521 с.

4. Кавказский Календарь за 1880 год (високосный): 35-й год / [под ред. действит. стат. советника Шаврова]. - 1879. - Тифлис: Гл. упр. Кавказ. наместника, 1845-1916. - 552 с.

5. Кавказский Календарь за 1881 год: 36-й год/ [под ред. действит. стат. советника Шаврова]. - 1880. - Тифлис: Гл. упр. Кавказ. наместника, 1845-1916. 545 c.

21 Обзор Карсской области за 1910 год, с. 41.

22 Candan Badem. Çarlık Yönetiminde Kars, Ardahan, Artvin 1878-1918, s.322.

23 Candan Badem. Çarlık Yönetiminde Kars, Ardahan, Artvin 1878-1918, s.322.

24 Обзор Карсской области за 1909 год, с. 42. 
6. Кавказский Календарь за 1882 год: 37-й год - 1881. - Тифлис: Гл. упр. Кавказ. наместника, 1845-1916. - 640 с.

7. Кавказский Календарь за 1883 год: 38-й год - 1882. - Тифлис: Типография Гл. упр. Главнонач. Гражданской частью на Кавказе. - 504 с.

8. К Кавказский Календарь за 1884 год: 39-й год: (високосный). - 1883. - [4], 256. - Тифлис: Гл. упр. Кавказ. наместника, 1845-1916. - 204 с.

9. Кавказский Календарь за 1885 год: 40-й год / [под ред. надв. советника Е. Кондратенко]. - 1884. - [4], 309. - Тифлис: Гл. упр. Кавказ. наместника, 1845-1916. - 208 c.

10. Кавказский Календарь за 1886 год: 41-й год. - 1885. - [4], 236, VI. - Тифлис: Гл. упр. Кавказ. наместника, 1845-1916. - 206 с.

11. Кавказский Календарь за 1887 год: 42-й год. - 1886. - Тифлис: Гл. упр. Кавказ. наместника, 1845-1916. - 503 с.

12. Кавказский Календарь за 1888 год: 43-й год. - 1887. - Тифлис: Гл. упр. Кавказ. наместника, 1845-1916. - 542 с.

13. Кавказский Календарь за 1889 год: 44-й год. - 1888. - Тифлис: Гл. упр. Кавказ. наместника, 1845-1916. - 530 с.

14. Кавказский Календарь за 1890 год: 45-й год. - 1889. - Тифлис: Гл. упр. Кавказ. наместника, 1845-1916. - 413 с.

15. Кавказский Календарь за 1891 год: 46-й год. - 1890. - Тифлис: Гл. упр. Кавказ. наместника, 1845-1916. - 652 с.

16. Кавказский Календарь за 1892 год: 47-й год. - 1891. - Тифлис: Гл. упр. Кавказ. наместника, 1845-1916. - 377 с.

17. Кавказский Календарь за 1893 год: 48-й год. - 1892. - Тифлис: Гл. упр. Кавказ. наместника, 1845-1916. - 692 с.

18. Кавказский Календарь за 1894 год: 49-й год. - 1893. - Тифлис: Типография Гл. упр. Главнонач. Гражданской частью на Кавказе. - 694 с.

19. Кавказский Календарь за 1895 год: 50-й год. - 1894. - Тифлис: Типография Гл. упр. Главнонач. Гражданской частью на Кавказе. - 656 с.

20. Кавказский Календарь за 1896 год: 51-й год. - 1895. - Тифлис: Гл. упр. Кавказ. наместника, 1845-1916. - 848 с.

21. Кавказский Календарь за 1897 год: 52-й год. - 1896. - Тифлис: Гл. упр. Кавказ. наместника, 1845-1916. - 584 с.

22. Кавказский Календарь за 1898 год: 53-й год / под ред. стат. советника Е. Кондратенко. - 1897. - Тифлис: Гл. упр. Кавказ. наместника, 1845-1916. - 550 с.

23. Кавказский Календарь за 1899 год: 54-й год / под ред. стат. советника Е. Кондратенко. - 1898. - Тифлис: Гл. упр. Кавказ. наместника, 1845-1916. - 560 с.

24. Кавказский Календарь за 1900 год: 55-й год / под ред. стат. советника Е. Кондратенко. - 1899. - Тифлис: Гл. упр. Кавказ. наместника, 1845-1916. - 530 с.

25. Кавказский Календарь за 1901 год: 56-й год. - 1900. - Тифлис: Гл. упр. Кавказ. наместника, 1845-1916. - 510 с.

26. Кавказский Календарь за 1902 год: 57-й год. - 1901. - Тифлис: Гл. упр. Кавказ. наместника, 1845-1916. - 651 с.

27. Кавказский Календарь за 1903 год: 58-й год. - 1902. - Тифлис: Типография Главнонач. Гражданской частью на Кавказе., 1845-1916. - 751 с.

28. Кавказский Календарь за 1904 год: 59-й год. - 1903. - Тифлис: Гл. упр. Кавказ. наместника, 1845-1916. - 533 с.

29. Кавказский Календарь за 1905 год: 60-й год. - 1904. - Тифлис: Гл. упр. Кавказ. наместника, 1845-1916. - 535 с.

30. Кавказский Календарь за 1906 год: 61-й год. - 1906. - Тифлис: Гл. упр. Кавказ. наместника, 1845-1916. - 355 с.

31. Кавказский Календарь за 1907 год 62-й год: С прил. карты Кавказа и плана г. Тифлиса / под ред. Д.Д. Пагирева. - Закавказ. стат. ком., 1906. - Тифлис: Гл. упр. Кавказ. наместника, 1845-1916. - 626 с.

32. Кавказский Календарь за 1908 год: 63-й год / под ред. Д.Д. Пагирева. - Закавказ. стат. ком., 1907. - Тифлис: Гл. упр. Кавказ. наместника, 1845-1916. $690 \mathrm{c}$.

33. Кавказский Календарь за 1909 год: 64-й год. - 1908. - Тифлис: Гл. упр. Кавказ. наместника, 1845-1916. - 1251 с.

34. Кавказский Календарь за 1910 год: 65-й год, ч. 1 / под ред. В.В. Стратонова. - [1909]. - Тифлис: Гл. упр. Кавказ. наместника, 1845-1916. - VIII, 928 с.

35. Кавказский Календарь за 1910 год: 65-й год. Ч. 2. - [1909]. - Тифлис: Гл. упр. Кавказ. наместника, 1845-1916. - 363 с.

36. Кавказский Календарь за 1911 год: 66-й год. - 1910. - Тифлис: Гл. упр. Кавказ. наместника, 1845-1916. - 285 с.

37. Кавказский Календарь за 1912 год: 67-й год. - 1911. - Тифлис: Гл. упр. Кавказ. наместника, 1845-1916. - 620 с.

38. Кавказский Календарь за 1913 год: 68-й год: С приложениями: 1. Справочная книга по городу Тифлису 2. Краткий путеводитель по Кавказу. - 1912. Тифлис: Гл. упр. Кавказ. наместника, 1845-1916. - 893 с.

39. Кавказский Календарь за 1914 год: 69-й год. - 1913. - Тифлис: Гл. упр. Кавказ. наместника, 1845-1916. - 977 с.

40. Кавказский Календарь за 1915 год: 70-й год. - 1914. - Тифлис: Гл. упр. Кавказ. наместника, 1845-1916. - 1013 с.

41. Кавказский Календарь за 1916 год: 71-й год / под ред. Н. П. Стельмащука. - 1915. - Тифлис: Гл. упр. Кавказ. наместника, 1845-1916. - 627 с.

42. Кавказский Календарь за 1917 год: $72-$ й год: с приложением карт Кавказа, Азиатской Турции и Персии / под ред. Н. П. Стельмащука. - 1916. - Тифлис: Гл. упр. Кавказ. наместника, 1845-1916. - 1231 с.

43. Обзор Карсской области за 1894 год [по годам]. - Карс: Тип. канцелярии воен. губернатора Карсск. обл., 1895-1914. - За ряд лет: Прил. ко всеподд. отчету воен. губернатора Карсск. обл. -1895.77 с.

44. Обзор Карсской области за 1895 год [по годам]. - Карс: Тип. канцелярии воен. губернатора Карсск. обл., 1895-1914. - За ряд лет: Прил. ко всеподд. отчету воен. губернатора Карсск. обл. - 1896.65 с.

45. Обзор Карсской области за 1896 год [по годам]. - Карс: Тип. канцелярии воен. губернатора Карсск. обл., 1895-1914. - За ряд лет: Прил. ко всеподд. отчету воен. губернатора Карсск. обл. - 1897.97 с.

46. Обзор Карсской области за 1897 год [по годам]. - Карс: Тип. канцелярии воен. губернатора Карсск. обл., 1895-1914. - За ряд лет: Прил. ко всеподд. отчету воен. губернатора Карсск. обл. - 1898.91 с.

47. Обзор Карсской области за 1898 год [по годам]. - Карс: Тип. канцелярии воен. губернатора Карсск. обл., 1895-1914. - За ряд лет: Прил. ко всеподд. отчету воен. губернатора Карсск. обл. - 1899. -103 с.

48. Обзор Карсской области за 1899 год [по годам]. - Карс: Тип. канцелярии воен. губернатора Карсск. обл., 1895-1914. - За ряд лет: Прил. ко всеподд. отчету воен. губернатора Карсск. обл. - 1900. - 90 с.

49. Обзор Карсской области за 1902 год [по годам]. - Карс: Тип. канцелярии воен. губернатора Карсск. обл., 1895-1914. - За ряд лет: Прил. ко всеподд. отчету воен. губернатора Карсск. обл. - 1903. - 21 с. 
50. Обзор Карсской области за 1903 год [по годам]. - Карс: Тип. канцелярии воен. губернатора Карсск. обл., 1895-1914. - За ряд лет: Прил. ко всеподд. отчету воен. губернатора Карсск. обл. - 1904. - 47 с.

51. Обзор Карсской области за 1904 год [по годам]. - Карс: Тип. канцелярии воен. губернатора Карсск. обл., 1895-1914. - За ряд лет: Прил. ко всеподд. отчету воен. губернатора Карсск. обл. - 1905. - 51 с.

52. Обзор Карсской области за 1905 год [по годам]. - Карс: Тип. канцелярии воен. губернатора Карсск. обл., 1895-1914. - За ряд лет: Прил. ко всеподд. отчету воен. губернатора Карсск. обл. - 1905. - 51 с.

53. Обзор Карсской области за 1906 год [по годам]. - Карс: Тип. канцелярии воен. губернатора Карсск. обл., 1895-1914. - За ряд лет: Прил. ко всеподд. отчету воен. губернатора Карсск. обл. - 1907. - 51 с.

54. Обзор Карсской области за 1907 год [по годам]. - Карс: Тип. канцелярии воен. губернатора Карсск. обл., 1895-1914. - За ряд лет: Прил. ко всеподд. отчету воен. губернатора Карсск. обл. - 1908. - 51 с.

55. Обзор Карсской области за 1908 год [по годам]. - Карс: Тип. канцелярии воен. губернатора Карсск. обл., 1895-1914. - За ряд лет: Прил. ко всеподд. отчету воен. губернатора Карсск. обл. - 1909. - 51 с.

56. Обзор Карсской области за 1909 год [по годам]. - Карс: Тип. канцелярии воен. губернатора Карсск. обл., 1895-1914. - За ряд лет: Прил. ко всеподд. отчету воен. губернатора Карсск. обл. - 1910. - 112 с.

57. Обзор Карсской области за 1910 год [по годам]. - Карс: Тип. канцелярии воен. губернатора Карсск. обл., 1895-1914. - За ряд лет: Прил. ко всеподд. отчету воен. губернатора Карсск. обл. - 1911. - 113 с.

58. Обзор Карсской области за 1912 год [по годам]. - Карс: Тип. канцелярии воен. губернатора Карсск. обл., 1895-1914. - За ряд лет: Прил. ко всеподд. отчету воен. губернатора Карсск. обл. - 1914. - 16 с.

59. Candan Badem. Çarlık Yönetiminde Kars, Ardahan, Artvin 1878-1918. Topkapı - İstanbul, Aras Yayıncılık, 2018. - 632 s.

(c) Пестовская Дарья Александровна (daryagreen@yandex.ru).

Журнал «Современная наука: актуальные проблемы теории и практики»

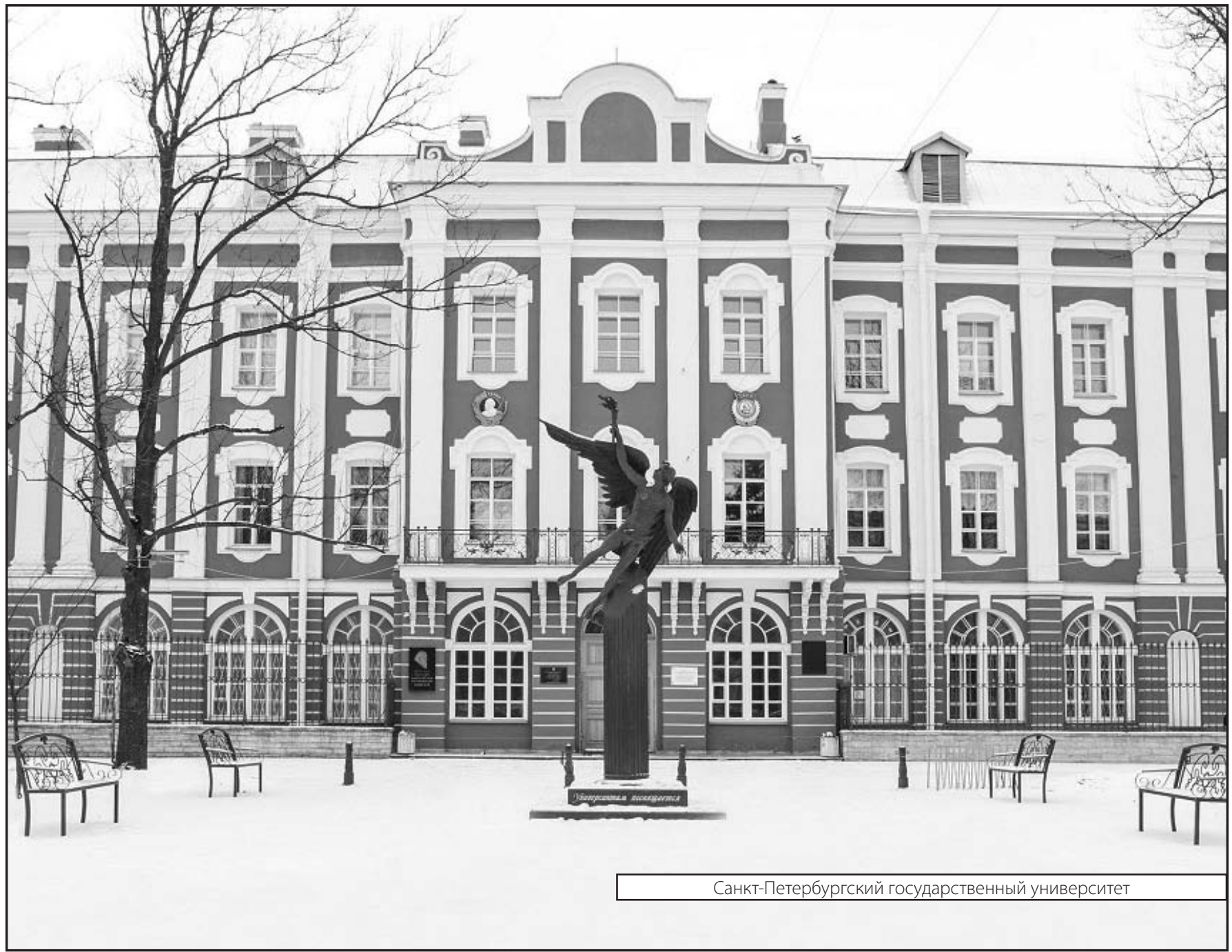

